\title{
Allelopathic effects of dominant ground vegetation species on initial growth of Pinus sylvestris L. seedlings in response to different temperature scenarios
}

\author{
Vaida Sirgedaitè-Šěžiene ${ }^{(1)}$, \\ Ligita Baležentienè ${ }^{(2)}$, \\ Iveta Varnagirytė-Kabašinskienè ${ }^{(1)}$, \\ Vidas Stakènas ${ }^{(1)}$, \\ Virgilijus Baliuckas ${ }^{(1)}$
}

\begin{abstract}
The dominant species of ground vegetation cover in clear-cuts impact the regeneration of Scots pine forests due to the biochemical properties of these dominant species. Environmental conditions in clear-cuts, specifically increased light and temperature, can alter the biochemical impact of dominant species on subsequent Scots pine regeneration processes. To investigate this, plant species diversity, frequency and cover were estimated in order to identify the dominant species of ground vegetation in clear-cut areas over a two-year period. Afterward, the impact of dominant species extracts on pine seed germination and seedling physiology at different temperature scenarios was evaluated. The species Pleurozium schreberi (Brid.) Mitt., Vaccinium vitis-idaea L. and Calluna vulgaris (L.) Hull were recorded as dominant in 1-yr-old clear-cut areas, and Vaccinium vitis-idaea L., Rumex acetosella L., and Calamagrostis epigejos (L.) Roth were dominant in 2-yrold clear-cut areas. The prepared aqueous extracts of all dominant species exhibited strong inhibitory effects on pine seed germination and seedling morpho-physiological traits (the length of the radicle and hypocotyl; chlorophyll $a, b, a / b$ and carotenoid content), resulting in the reduction of ex situ pine adaptive capacity at higher air temperature $\left(24^{\circ} \mathrm{C}\right)$ compared to that at lower temperature $\left(20^{\circ} \mathrm{C}\right)$. Significantly $(p<0.05)$ stronger inhibitory effects of root and shoot extracts produced from all dominant species on chlorophyll $a, b$ and $a / b$ content were recorded at higher temperature $\left(22-24^{\circ} \mathrm{C}\right)$ compared to lower $\left(20^{\circ} \mathrm{C}\right)$ temperature. A significantly lower content of carotenoids was observed in the control $\left(24^{\circ} \mathrm{C}\right)$ temperature. Thus, a high increase of ambient temperature may cause unfavourable conditions for Scots pine seedling growth in boreal forests.
\end{abstract}

Keywords: Carotenoids, Chlorophylls, Clear-cut, Germination, Plant Extract

\section{Introduction}

The phenomenon of allelopathy is defined as the process of plant-plant chemical interaction that results in either positive or negative effects (Donnelli et al. 2008). Allelochemicals, which are regarded as secondary metabolites, are natural products delivered through decomposition, volatilization, leaching, and root exudation (Ruan et al. 2016). They play an important role in the distribution of plant populations, the succession of communities, the nutrient chelation, and also in physiological processes (Wardle et al. 2011, Vanderstukken et al. 2014,). It is still under discussion if allelopathy may drive forest succession and ecosystem-level allelopathic effect may cause the regeneration failure of conifers. The wide range of biochemical compounds produced by plants can determine diverse biological changes (Heidarzadeh et al. 2010).

Typically, donor plants increase both the production and release of secondary me-
(1) Institute of Forestry, Lithuanian Research Centre for Agriculture and Forestry, LT-53101 (Lithuania); (2) Institute of Environment and Ecology, Aleksandras Stulginskis University, LT53361 (Lithuania)

@ Vaida Sirgedaitè-Šèžiene (vaida.seziene@mi.lt)

Received: Jun 25, 2018 - Accepted: Dec 28, 2018

Citation: Sirgedaite-Seziene V, Balezentiene L, Varnagiryte-Kabasinskiene I, Stakenas V, Baliuckas V (2019). Allelopathic effects of dominant ground vegetation species on initial growth of Pinus sylvestris L. seedlings in response to different temperature scenarios. iForest 12: 132-140. - doi: 10.3832/ifor2904-012 [online 2019-02-27]

Communicated by: Silvano Fares tabolites under stress conditions, and this consequently causes a higher allelochemical concentration in the environment (Seziene et al. 2017). Allelochemicals, among other environmental factors - both abiotic (temperature, light, moisture, nutrients) and biotic (herbivores, pathogens) - synergistically affect various functions of plant species, such as their regeneration ability (Oyun 2006). However, few studies have investigated plant occurrence and regeneration in response to the concomitant effect of several environmental factors (Ping et al. 2009). Climatic changes influence the ecological environment and this can undoubtedly affect the recruitment and population dynamics of plants. Early stages of plant growth are expected to be more sensitive to climate change than adult stages and, as such, represent a main obstacle to recruitment (Donohue et al. 2010). Seedling emergence is usually synchronized with seasonal changes in the environment (Ruan et al. 2016). For the plasticity/adaptations of tree species, however, we know very little about their germination behavior in response to environmental changes (Berner et al. 2013). 
Moreover, the response of seedlings to increased temperature is not fully understood. It is known that temperature affects photosynthesis and respiration processes, i.e., higher-than-optimal temperature increases respiration but inhibits the intensity of photosynthesis (Santos et al. 2009).

A reduction in chlorophyll content is a common plant response to the impact of allelochemicals (Benyas et al. 2010, Heidarzadeh et al. 2012). Allelochemicals can reduce chlorophyll accumulation in three ways through: (i) the inhibition of chlorophyll synthesis; (ii) the stimulation of chlorophyll degradation; and (iii) both the inhibition and stimulation together (Heidarzadeh et al. 2012). Often, changes in chlorophyll synthesis are a consequence of plant response to cellular damage due to allelochemicals (Benyas et al. 2010), thus causing poor plant growth (Rashed Mohasel \& Moosavi 2007).

Species with a wide distribution are especially useful to test changes in recruitment patterns as a consequence of climate alterations, as they grow under strongly different ecological conditions across their range. Scots pine (Pinus sylvestris L.) has the largest geographical distribution among pine species, and is one of the most widespread conifers on Earth, distributed from the Mediterranean to the Arctic (Matias et al. 2012). This wide latitudinal distribution results in this species growing under strongly differentiated environmental conditions throughout its range, with the greatest contrast at northern and southern range edges (Matias \& Jump 2014). Consequently, Scots pine is an important study species for the detection of variation in recruitment patterns across wide geographical areas.

The goal of this study was to evaluate the allelopathic activity of aqueous extracts produced from both shoots and roots of 1yr-old and 2-yr-old ground-vegetation dominant species grown in clear-cuts of Scots pine stands (Pinetum vacciniosum) in response to different temperature regimes ex situ. A multifunctional experiment was designed in order to reveal the implications and interactions between allelopathic and plant development parameters (species and plant parts) on Scots pine seed germination and morpho-physiological traits of seedlings.

\section{Materials and methods}

\section{Dominant species}

The study was conducted in a Scots pine forest site at the Trakai Forest Enterprise located in the south-eastern part of Lithuania $\left(54^{\circ} 30^{\prime}-54^{\circ} 38^{\prime} \mathrm{N}, 24^{\circ} 50^{\prime}-25^{\circ} 00^{\prime} \mathrm{E}\right)$. The successional stages of herbaceous phytocoenoses were surveyed in 1-yr-old and 2-yr-old clear-cuts after reforestation of Scots pine stands during summer (JuneJuly). In total, seventeen clear-cuts, including eight 1-yr-old and nine 2-yr-old clearcuts, were evaluated. The soil in the site was classified as Arenosol (WRB-IWG 2014). The forest type was Pinetum vacciniosum, and the forest site type was $\mathrm{Nb}$ - oligotrophic mineral soil of normal moisture, according to the Lithuanian classification (LR-AM/LMI/VMT 2006). The mean annual temperature in $1981-2010$ was $6.9^{\circ} \mathrm{C}$ (standard climatic normal [CN] of 1961-1990 was $6.2{ }^{\circ} \mathrm{C}$ ) and the mean annual precipitation in 1981-2010 was $686 \mathrm{~mm}$ (SN of 1961-1990 was $675 \mathrm{~mm}$ ). Frequency (\%) and relative plant cover (\%) of ground vegetation species were assessed in accordance with the Braun-Blanquet (1964) scale (Tab. 1). Subsequently, the dominant species (henceforth: dominants) were sampled to obtain aqueous extracts for the assessment of their allelochemical impact on potential acceptor species. Seed germination and seedling growth of acceptor Scots pine trees were assessed as the main indicators of the biochemical impact of dominants on the initial stages of forest regeneration in the clear-cuts.

\section{Pigment bioassays}

The fresh dominant plants were sampled during mid-day in the 1- and 2-yr-old forest clear-cuts after reforestation. The samples were collected from three 1-yr-old and three 2-yr-old forest clear-cuts. The samples were transported to laboratory in plastic bags. For the production of $0.2 \%$ aqueous extract concentrations, air-dried plant parts (roots and shoots) were chopped into pieces of $2 \mathrm{~cm}$. Twenty grams of biomass was placed in glass bottles filled with $100 \mathrm{ml}$ of distilled water, covered with foil, shaken several times, maintained for approximately 12 hours at $18-20{ }^{\circ} \mathrm{C}$ and then filtered (Balezentiene \& Seziene 2010). The extract $\mathrm{pH}$ was measured with a $\mathrm{pH}$ meter

Tab. 1 - Mean ( \pm standard deviation) frequency and cover of the dominant species of ground vegetation recorded in the clear-cuts of Scots pine stands.

\begin{tabular}{llcr}
\hline $\begin{array}{l}\text { Age of } \\
\text { clear-cuts }\end{array}$ & Dominant species & Frequency (\%) & Cover (\%) \\
\hline 1-yr-old & Pleurozium schreberi (Brid.) Mitt & $96.9 \pm 4.3$ & $9.7 \pm 5.4$ \\
& Vaccinium vitis-idaea L. & $95.3 \pm 5.7$ & $10.2 \pm 3.0$ \\
& Calluna vulgaris (L.) Hull & $86.5 \pm 17.1$ & $6.3 \pm 1.8$ \\
\multirow{2}{*}{ 2-yr-old } & Vaccinium vitis-idaea L. & $90.7 \pm 6.5$ & $12.2 \pm 1.6$ \\
& Calamagrostis epigejos (L.) Roth & $44.0 \pm 8.6$ & $5.6 \pm 1.1$ \\
& Rumex acetosella L. & $68.1 \pm 16.1$ & $2.9 \pm 1.1$ \\
\hline
\end{tabular}

(CyberScan Series $600^{\oplus}$ waterproof portable meter, Eutechinst Instruments, Singapore).

The germination of acceptor pine seeds was assessed according to the International Seed Testing Association (ISTA 2007). One hundred sterilized Scots pine seeds taken from Forest Seed and Plant Quality Department of Lithuanian State Forest Service were placed on filter paper in a 9-cmdiameter Petri dish. Five millilitres of $0.2 \%$ extract was added to each Petri dish and covered. Each treatment consisted of three replicates with one hundred Scots pine seeds. For the control, seeds were sown in the distilled water. Additional five millilitres of distilled water (control) and dominant plants aqueous extracts (treatments) were added in Petri dishes every five days over the germination period.

For seed germination analysis, all Petri dishes were stored at controlled temperature conditions that consisted of four different temperature regimes $(18,20,22$ and $24^{\circ} \mathrm{C}$ ) for 21 days. The germination rate was assessed every 7 days, i.e., after 7, 14 and 21 days. At the end of the experiment, the length of the radicle and hypocotyl was measured. In addition, $0.2 \mathrm{~g}$ of fresh pine seedling shoot was sampled for chlorophyll $a$ and $b$ (chl $a$ and $\mathrm{chl} b$ ) and carotenoid assays, with 3 replications per treatment. The content of carotenoids and chl $a$ and $b$ (mg $\mathrm{g}^{-1}$ ) was estimated spectrometrically (Shimadzu UV-1800 ${ }^{\circledast}$, Shimadzu Corp., Japan) at $440.5,662$ and $644 \mathrm{~nm}$ wavelengths $(D)$, respectively. For the calculation of pigment contents, the following equations were used (Wettstein 1957 - eqn. 1, eqn. 2, eqn. 3):

$$
\begin{aligned}
& \text { chl } a=9.784 \cdot D_{662}-0.990 \cdot D_{664} \frac{c \cdot V}{P \cdot 1000} \\
& \begin{array}{r}
\text { chlb }=21.426 \cdot D_{644}-4.650 \cdot D_{662} \frac{c \cdot V}{P \cdot 1000} \\
\text { Carotenoid }=4.695 \cdot D_{440.5} \\
-0.268 \cdot(\text { chla }+b) \frac{c \cdot V}{P \cdot 1000}
\end{array}
\end{aligned}
$$

where $c$ is the pigment content $\left(\mathrm{mg} \mathrm{g}^{-1}\right), \mathrm{V}$ is the extract volume $(\mathrm{ml})$, and $P$ is the fresh mass of seedling needles ( $g$ ).

Laboratory analyses were performed at the Institute of Forestry of the Lithuanian Research Center for Agriculture and Forestry (LAMMC).

\section{Statistical data analysis}

The confidence limits of the data were assessed by Wilkin's $\lambda$-test and Fisher's theoretical criterion ( $F$ ). Standard deviations (SD) were calculated at the level of statistical significance of $p<0.05$. The results of allelopathic effects were evaluated using the statistical package STATISTICA ${ }^{\oplus}$ (StatSoft Inc., Tulsa, OK, USA). The Student $t$-test ( $t$ ) and Kolmogorov-Smirnov (KS) test were used to determine statistically significant differences in germination rates and morpho-physiological parameters under differ- 
ent temperature regimes. Redundancy analysis (RDA) was used to determine the relationships between different temperatures and germination rates, the effects of dominant species and their parts on morphometric parameters, analysed using the software $\mathrm{XLSTAT}^{\circledast}$ (Exeter, Setauket, NY, USA). The SAS MIXED procedure (REML method) was used to determine which effect had the strongest impact on the obtained data variability (SAS Institute Inc. 2010). Statistical analysis was performed in order to determine which factor or interaction had the strongest impact on the variability of the obtained data. The effects of fixed parameters, i.e., temperature and extract $\mathrm{pH}$ group $(1: 2.0<\mathrm{pH} \leq 4.9 ; 2: 4.9<\mathrm{pH}$ $\leq 5.9 ; 3: 5.9<\mathrm{pH}<7.0$ ) were evaluated by means of the TEST3 method.

The initial SAS MIXED procedure was performed according to the following model (eqn. 4):

$$
\begin{aligned}
y_{i j k l m n} & =\mu+s_{i}+p_{j}+h_{k}+r_{l}+d_{m}+r h_{l k} \\
& +d h_{m k}+r s_{l i}+d s_{m i}+\varepsilon_{i j k l m n}
\end{aligned}
$$

where $y_{\mathrm{ijk} m \mathrm{~m}}$ is the response value for the $\mathrm{n}$ th observation; $\mu$ is the overall mean; $s_{i}$ is the fixed effect for the $i$-th temperature; $p_{\text {i }}$ is the fixed effect for the $j$-th replication; $h_{k}$ is the fixed effect for the $k$-th $\mathrm{pH}$ group; $r_{1}$ is the random effect for the l-th species; $d_{m}$ is the random effect for the $m$-th plant part; $r h_{\mathbb{l}}$ is the random effect for the interaction of the 1 -th species and $k$-th $\mathrm{pH}$ group; $d h_{m k}$ is the random effect for the $m$ th plant part and $k$-pH group interaction; $r s_{\mathrm{li}}$ is the random effect for the $\mathrm{l}$-th species and $i$-th temperature interaction; $d s_{\mathrm{mi}}$ is the random effect for the $m$-th plant part and the $i$-th temperature interaction; and $\varepsilon_{\mathrm{ijk} k \mathrm{mn}}$ is the random error.

Furthermore, a series of models with fixed effects from model (4) but with a single random effect were included. Therefore, we finally obtained six models associated with respective random effects. This part of the statistical analysis was performed using the software SAS/STAT ver. 9.3 (SAS Institute Inc. 2010).

\section{Results}

Pleurozium schreberi and Vaccinium vitisidaea were detected in $97 \%$ and $95 \%$ of the experimental plots in the 1-yr-old clearcuts, respectively. The next dominant species was Calluna vulgaris at a frequency of $87 \%$. The relative plant cover of Vaccinium vitis-idaea increased by $2 \%$ and reached $12 \%$ in the 2-yr-old clear-cuts. Therefore, this species ensured a dominating position in relation to that of other plants. Mean frequencies of $44 \%$ and $68 \%$ were recorded for Calamagrotis epigejos and Rumex acetosella, respectively. These two species were classified as dominants due to their vigorous and various spreading abilities (both generative and vegetative), and these species structurally altered the phytocoenoses that was previously established in the clear-cuts.

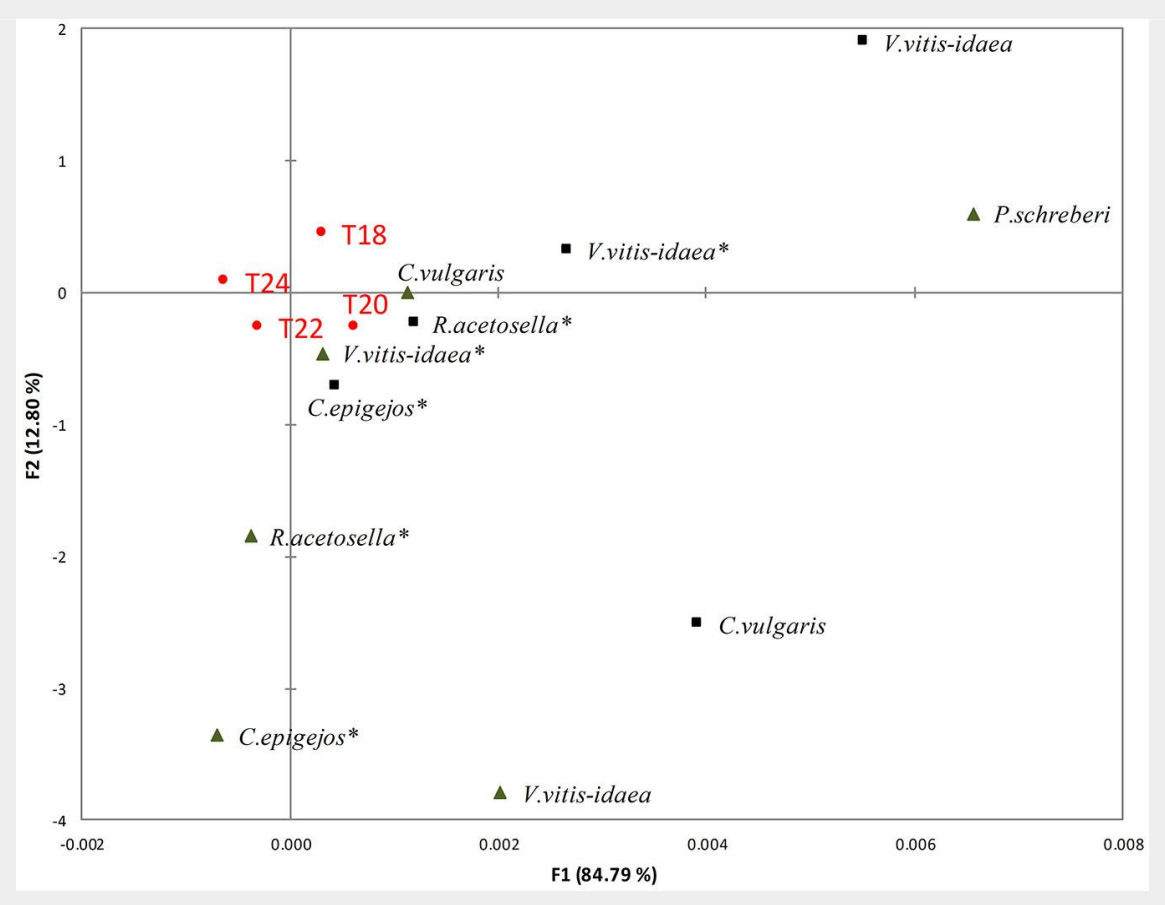

Fig. 1 - RDA of the impact of the shoots (black triangles) and roots (black squares) of dominant species aqueous extracts on germination at different temperatures (T18:18 $\left.{ }^{\circ} \mathrm{C} ; \mathrm{T} 20: 20^{\circ} \mathrm{C} ; \mathrm{T} 22: 22^{\circ} \mathrm{C} ; \mathrm{T} 24: 24^{\circ} \mathrm{C}\right)$. (*): dominant species of 2-yr-old clear-cuts.

\section{Effects on pine germination and}

seedling morphology

The phytotoxic impact of aqueous extracts on seed germination and hypocotyl and radicle length were dependent on dominant species, plant part, age of clearcut and temperature scenario (Fig. 1, Fig. 2, Fig. 3).

The weakest suppressive effect on germination rate was determined for all dominant species at $20^{\circ} \mathrm{C}$. The inhibitory effect of dominant species increased with increasing temperature. RDA revealed that seed germination at $20^{\circ} \mathrm{C}$ was less affected by shoot extracts of $\mathrm{V}$. vitis-idaea and root extracts of C. vulgaris sampled in the 1-yrold clear-cuts. The $22{ }^{\circ} \mathrm{C}$ temperature was favourable for germination with the shoot extracts of R. acetosella and C. epigejos of 2yr-old clear-cuts.

A significant $(p<0.05)$ decrease in germination rate was determined for shoot extracts of $V$. vitis-idaea and $R$. acetosella when the temperature increased from 20 to $22^{\circ} \mathrm{C}$ (Tab. 2).

The Kolmogorov-Smirnov test revealed a significant inhibition of $P$. schreberi extracts $(p<0.01)$ and $C$. epigejos shoot extracts $(p<0.01)$ on pine seed germination rates. Seed germination inhibition significantly increased when the temperature increased from 20 to $24{ }^{\circ} \mathrm{C}$ (Tab. 2). A significantly strongest inhibition of seed germination was recorded for the shoot extracts of $V$.
Tab. 2 - Kolmogorov-Smirnov test results for germination rate at different tempera-

\begin{tabular}{|c|c|c|c|c|c|c|c|c|}
\hline \multirow{2}{*}{ 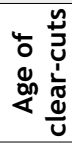 } & \multirow{2}{*}{ Extract } & \multirow[b]{2}{*}{ Dominant species } & \multicolumn{6}{|c|}{ Temperature $\left({ }^{\circ} \mathrm{C}\right)$} \\
\hline & & & $18 / 20$ & $20 / 22$ & $20 / 24$ & $18 / 22$ & $18 / 24$ & $22 / 24$ \\
\hline \multirow{6}{*}{ 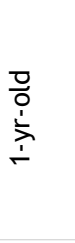 } & Shoot & P. schreberi & - & - & $* *$ & - & - & - \\
\hline & & V. vitis-idaea & * & - & - & * & - & * \\
\hline & & C. vulgaris & - & - & - & - & * & - \\
\hline & Root & P. schreberi & - & - & - & - & - & - \\
\hline & & V. vitis-idaea & - & $* *$ & $* *$ & * & $* *$ & - \\
\hline & & C. vulgaris & $* *$ & $* *$ & $* *$ & - & - & - \\
\hline \multirow{6}{*}{ 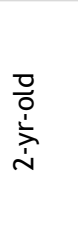 } & Shoot & V. vitis-idaea & - & - & - & - & - & - \\
\hline & & C. epigejos & - & - & $* *$ & - & - & $* *$ \\
\hline & & R. acetosella & - & * & - & - & - & - \\
\hline & Root & V. vitis-idaea & - & - & - & - & - & - \\
\hline & & C. epigejos & - & - & - & - & - & - \\
\hline & & R. acetosella & - & - & - & * & - & - \\
\hline
\end{tabular}
ture ratio simulations. $(*): p<0.05 ;(* *): p<0.01 ;(* * *): p<0.001$. 


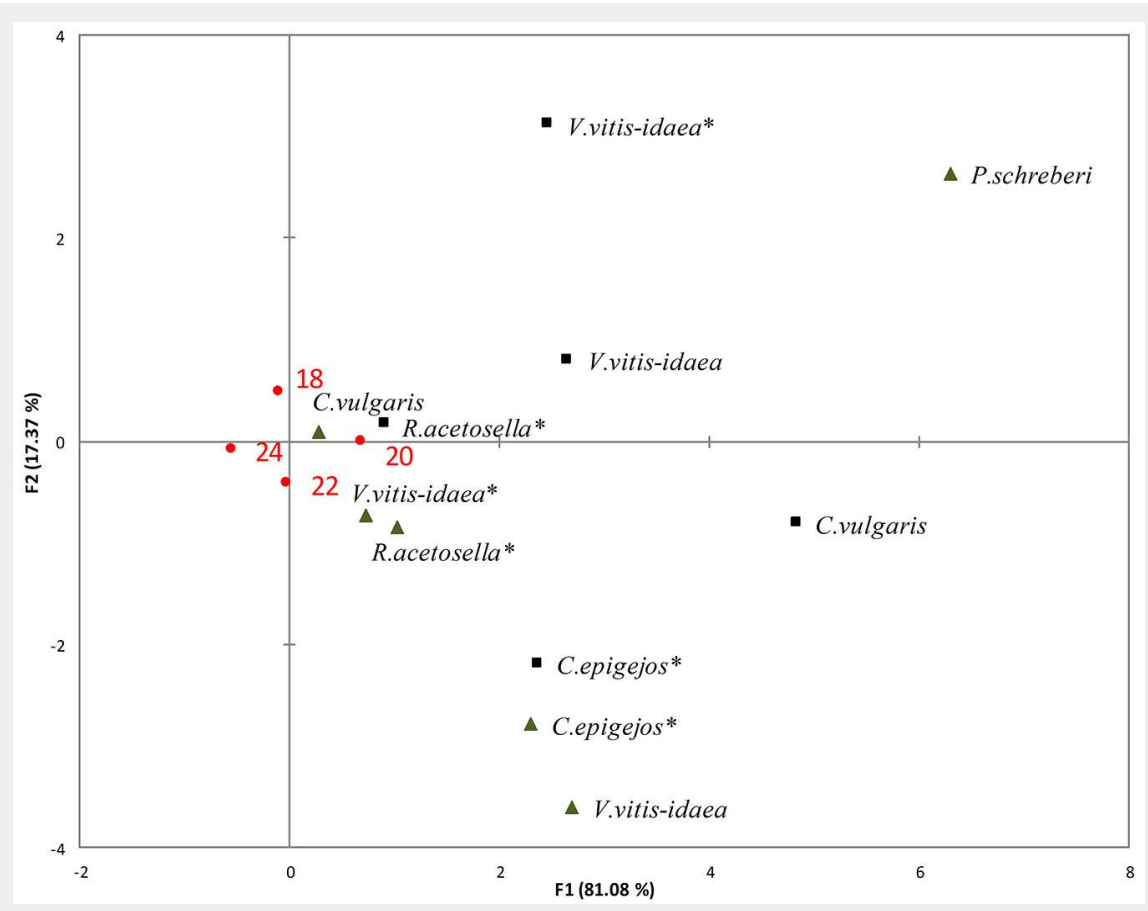

Fig. 2 - RDA of the impact of the shoots (black triangles) and roots (black squares) of dominant species aqueous extracts on the radicle length of seedlings at different temperatures $\left(\mathrm{T} 18: 18{ }^{\circ} \mathrm{C} ; \mathrm{T} 20: 20^{\circ} \mathrm{C} ; \mathrm{T} 22: 22^{\circ} \mathrm{C} ; \mathrm{T} 24: 24{ }^{\circ} \mathrm{C}\right) .\left({ }^{*}\right)$ : dominant species in the 2-yr-old clear-cuts.

vitis-idaea $(p<0.05)$ and C. epigejos $(p<0.01)$ when the temperature increased from 22 to $24^{\circ} \mathrm{C}$.

The primary growth of Scots pine seedling roots exhibited sensitivity to both shoot and root aqueous extracts of dominant species (Fig. 2). The inhibitory effect of different species and their parts, sam-

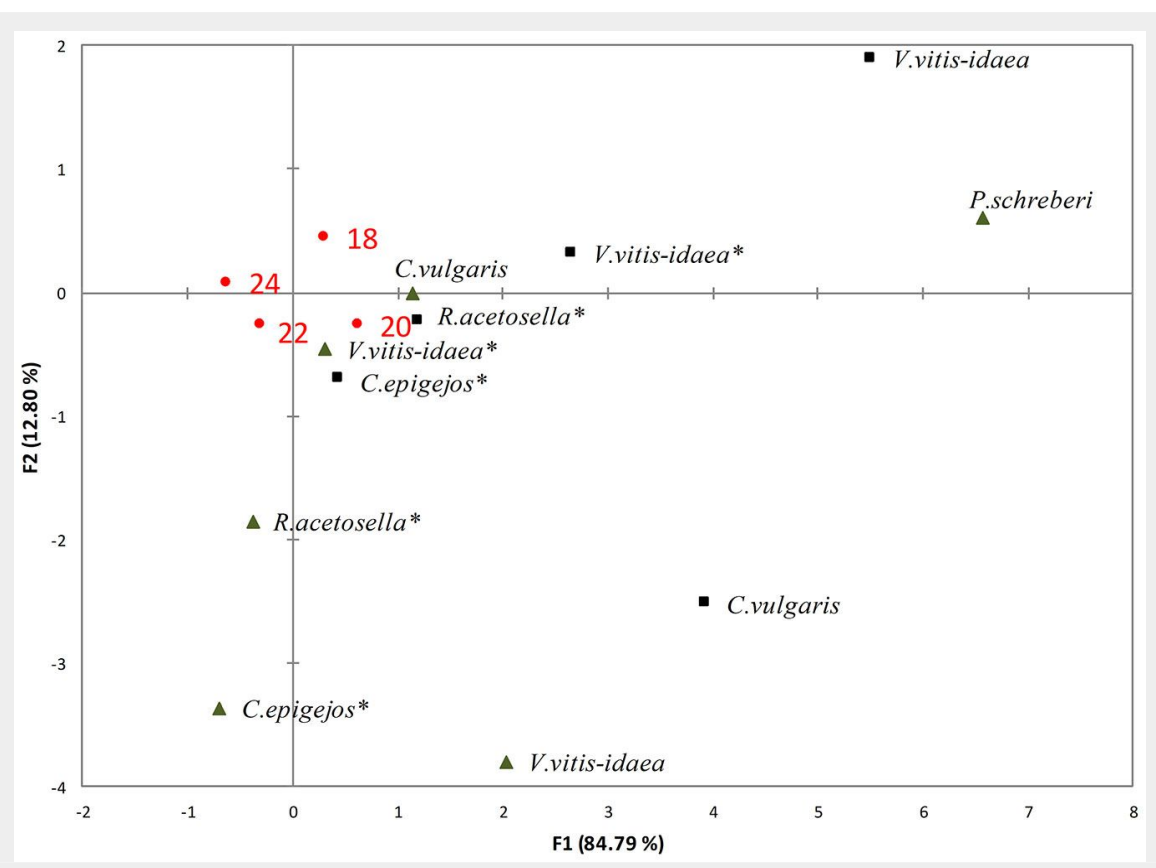

Fig. 3 - RDA of the impact of the shoots (black triangles) and roots (black squares) of dominant species aqueous extracts on hypocotyl length of pine seedlings at different temperatures $\left(\mathrm{T} 18: 18{ }^{\circ} \mathrm{C} ; \mathrm{T} 20: 20^{\circ} \mathrm{C} ; \mathrm{T} 22: 22^{\circ} \mathrm{C} ; \mathrm{T} 24: 24^{\circ} \mathrm{C}\right) .\left({ }^{*}\right)$ : dominant species in the 2-yr-old clear-cuts. old clear-cuts than by those of other dominant species. Moreover, radicle length of seedlings was severely affected by shoot extracts of $V$. vitis-idaea as well as both shoot and root extracts of R. acetosella of 2 -yr-old clear-cuts. The seed germination and radicle length of pine seedlings at $24^{\circ} \mathrm{C}$ were less conducive. Aqueous root extracts showed less inhibitory effects at all temperatures.

The increase in temperature from 20 to 22 ${ }^{\circ} \mathrm{C}$ and from 20 to $24{ }^{\circ} \mathrm{C}$ (Tab. 3) significantly decreased the radicle length of seedlings treated with aqueous root extracts of $\mathrm{V}$. vitis-idaea ( $p<0.05$ and $p<0.01$ for $20 / 22{ }^{\circ} \mathrm{C}$ and $20 / 24{ }^{\circ} \mathrm{C}$, respectively) and $C$. vulgaris $\left(p<0.05\right.$ and $p<0.001$ for $20 / 22{ }^{\circ} \mathrm{C}$ and $20 / 24$ ${ }^{\circ} \mathrm{C}$, respectively).

The weakest suppression of hypocotyl length and pine seed germination rate was determined for the majority of dominant species at $20^{\circ} \mathrm{C}$ temperature (Fig. 3). RDA revealed that the hypocotyl length of pine seedlings was severely affected by shoot extracts of $V$. vitis-idaea and root extracts of both C. epigejos and R. acetosella of 2-yrold clear-cuts at $20{ }^{\circ} \mathrm{C}$ temperature. Moreover, the hypocotyl length of pine seedlings was significantly inhibited by the shoot extracts of C. vulgaris of 1-yr-old clear-cuts. A temperature of $22^{\circ} \mathrm{C}$ was favourable for pine seedling hypocotyl growth in shoot extracts of $R$. acetosella and C. epigejos of 2-yr-old clear-cuts.

The weakest though still statistically significant inhibition was determined for $P$. schreberi extracts with changing temperature. Hypocotyl length significantly decreased in root extracts of $V$. vitis-idaea and $C$. vulgaris when the temperature increased from 20 to $22{ }^{\circ} \mathrm{C}(p<0.001$ and $p<0.01$, respectively) and from 20 to $24{ }^{\circ} \mathrm{C}(p<0.001$ and $p<0.001$, respectively).

\section{Allelopathic effects on pigment concentration}

The aqueous extracts of dominant species reduced the chlorophyll concentration in pine seedlings due to the biochemical impact (Tab. S1 in Supplementary material).

$\mathrm{Chl} a$ and chl $b$ concentration was severely affected by the shoot extracts of both $V$. vitis-idaea ( 0.35 and $0.15 \mathrm{mg} \mathrm{g}^{-1}$, respectively) of 1-yr-old clear-cuts and R. acetosella (0.28 and $0.12 \mathrm{mg} \mathrm{g}^{-1}$, respectively) of 2-yr-old clear-cuts at $18{ }^{\circ} \mathrm{C}$ temperature (Tab. S1). The roots of $R$. acetosella and C. epigejos sampled from 2-yr-old clear-cuts exhibited the strongest phytotoxicity on the concentration of chl $a\left(0.31 \mathrm{mg} \mathrm{g}^{-1}\right.$ and $0.12 \mathrm{mg} \mathrm{g}^{-1}$ for R. acetosella and C. epigejos, respectively) and chl $b$ ( 0.44 and $0.17 \mathrm{mg}$ $\mathrm{g}^{-1}$, respectively) obtained in pine seedlings. A strong inhibitory effect on chl $a$ and chl $b$ concentration in pine seedlings was caused by the shoot extracts of both $C$. vulgaris of 1-yr-old clear-cuts ( 0.62 and $0.23 \mathrm{mg} \mathrm{g}^{-1}$, respectively) and $V$. vitis-idaea of 2-yr-old clear-cuts (0.62 and $0.24 \mathrm{mg} \mathrm{g}^{-1}$, respectively) at $24^{\circ} \mathrm{C}$ temperature compared with that of the control. 
The chl $a / b$ ratio in the control pine seedlings increased with increasing temperature gradient, i.e., the value was 1.95 mg g-1 at $18{ }^{\circ} \mathrm{C}, 2.36 \mathrm{mg} \mathrm{g}^{-1}$ at $20^{\circ} \mathrm{C}, 2.53 \mathrm{mg}$ $\mathrm{g}^{-1}$ at $22{ }^{\circ} \mathrm{C}$ and $2.77 \mathrm{mg} \mathrm{g}^{-1}$ at $24^{\circ} \mathrm{C}$ (Tab. S1). In the control treatment, the increased chl $a / b$ ratio was mainly caused by increased chl a concentration.

The chl $a / b$ ratio in pine seedlings increased at $18{ }^{\circ} \mathrm{C}$ temperature in all extracts of dominant species due to faster chl b degradation, thus reducing the high risk of low-temperature stress on pine seedlings. The chl $a / b$ ratio at $20^{\circ} \mathrm{C}$ temperature was significantly strongly affected by the shoot extracts of both $R$. acetosella $\left(1.74 \mathrm{mg} \mathrm{g}^{-1}\right)$ and V. vitis-idaea $\left(1.84 \mathrm{mg} \mathrm{g}^{-1}\right)$ of 1-yr-old clear-cuts compared to those of the control (Tab. S1). When the temperature increased from $18-20{ }^{\circ} \mathrm{C}$ to $22{ }^{\circ} \mathrm{C}$, significantly $(p<0.05)$ stronger inhibitory effects were determined both for the root and shoot extracts of all dominant species of 1-yr-old clear-cuts and for the root and shoot extracts of C. epigejos and R. acetosella of 2yr-old clear-cuts compared with those of other dominant species. The $\mathrm{chl} a / b$ ratio was strongly inhibited by the shoot extracts of R. acetosella of 2-yr-old clear-cuts (2.37 mg g $\mathrm{m}^{-1}$ ) at $24^{\circ} \mathrm{C}$ temperature.

Nonetheless, the aqueous extracts of dominant species inhibited natural defensive reactions to stress exerted on pine seedlings, i.e., the treatment with extracts decreased the concentration of carotenoids (Tab. S1 in Supplementary material).

When comparing the allelopathic activity of different dominant species on carotenoid concentrations in pine seedlings at 18 ${ }^{\circ} \mathrm{C}$ and $20{ }^{\circ} \mathrm{C}$ temperatures, it was revealed that the carotenoid concentration was more affected by the shoot extracts of both C. vulgaris of 1-yr-old clear-cuts ( 0.15 and $0.13 \mathrm{mg} \mathrm{g}^{-1}$ for 18 and $20{ }^{\circ} \mathrm{C}$, respectively) and $R$. acetosella of 2-yr-old clearcuts ( 0.12 and $0.08 \mathrm{mg} \mathrm{g}^{-1}$, respectively). The extracts of all dominant species stimulated carotenoid concentrations increasing temperature from 18 to $22^{\circ} \mathrm{C}$. The weakest inhibitory effect at $22{ }^{\circ} \mathrm{C}$ temperature was caused by $P$. schreberi of 1-yr-old clear-cuts $\left(0.15 \mathrm{mg} \mathrm{g}^{-1}\right)$, the strongest inhibitory effect was caused by the shoot extracts of $R$. acetosella $\left(0.20 \mathrm{mg} \mathrm{g}^{-1}\right)$. The concentration of carotenoids in the control pine seedlings at $24{ }^{\circ} \mathrm{C}$ temperature significantly decreased $\left(0.02 \mathrm{mg} \mathrm{g}^{-1}\right)$ compared to that at $18^{\circ} \mathrm{C}$ temperature, at which the concentration was $0.16 \mathrm{mg} \mathrm{g}^{-1}$. At $20{ }^{\circ} \mathrm{C}$, the carotenoid concentration was $0.18 \mathrm{mg} \mathrm{g}^{-1}$; at $22^{\circ} \mathrm{C}, 0.25 \mathrm{mg}$ $\mathrm{g}^{-1}$.

The highest temperature of $24^{\circ} \mathrm{C}$ was the main factor that decreased pine seedling resistance to other stresses, specifically the effect of dominant species extracts. The largest decrease in chl a concentration was determined for the shoot and root extracts of both C. vulgaris of 1-yr-old clear-cuts and $R$. acetosella of 2-yr-old clear-cuts when the temperature increased from $18-20$ to $24^{\circ} \mathrm{C}$ (Tab. 4).
Tab. 3 - Results of the Kolmogorov-Smirnov test for radicle and hypocotyl length responses to extracts at different temperature ratio $\left({ }^{\circ} \mathrm{C}\right) .(*): p<0.05 ;(* *): p<0.01$; $(* * *): p<0.001$.

\begin{tabular}{|c|c|c|c|c|c|c|c|c|c|c|c|c|c|c|}
\hline \multirow{3}{*}{ 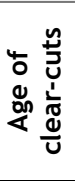 } & \multirow{3}{*}{ Extract } & \multirow{3}{*}{$\begin{array}{l}\text { Dominant } \\
\text { species }\end{array}$} & \multicolumn{12}{|c|}{ Temperature $\left({ }^{\circ} \mathrm{C}\right)$} \\
\hline & & & $\begin{array}{l}\stackrel{\text { N }}{\infty} \\
\stackrel{\infty}{\leftarrow}\end{array}$ & $\begin{array}{l}\text { N } \\
\text { D }\end{array}$ & $\begin{array}{l}\stackrel{ \pm}{N} \\
\stackrel{N}{N}\end{array}$ & $\begin{array}{l}\underset{N}{\infty} \\
\stackrel{\infty}{-}\end{array}$ & $\underset{\infty}{\stackrel{ \pm}{\infty}}$ & $\underset{N}{\stackrel{N}{N}}$ & 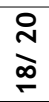 & 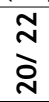 & $\begin{array}{l}\underset{N}{D} \\
\text { D }\end{array}$ & $\begin{array}{l}\underset{N}{\infty} \\
\stackrel{\infty}{-}\end{array}$ & $\underset{\infty}{\stackrel{ \pm}{\infty}}$ & $\underset{N}{\stackrel{J}{N}}$ \\
\hline & & & \multicolumn{6}{|c|}{ Radicle length (mm) } & \multicolumn{6}{|c|}{ Hypocotyl length (mm) } \\
\hline \multirow{5}{*}{ 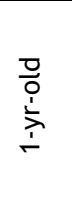 } & Shoot & P. schreberi & * & $* *$ & $* * *$ & - & $* *$ & - & - & $* * *$ & $* * *$ & $* *$ & $* * *$ & * \\
\hline & & V. vitis-idaea & $* *$ & - & $*$ & $* *$ & - & $* *$ & - & - & * & - & - & - \\
\hline & & C. vulgaris & - & - & - & - & - & - & - & - & - & - & - & - \\
\hline & Root & V. vitis-idaea & - & * & $* *$ & - & - & - & - & $* * *$ & $* * *$ & * & * & - \\
\hline & & C. vulgaris & - & * & $* * *$ & - & - & ** & - & $* *$ & $* * *$ & - & * & $* * *$ \\
\hline \multirow{6}{*}{$\begin{array}{l}\text { 뭉 } \\
\stackrel{1}{\lambda} \\
\dot{\lambda} \\
\dot{\sim}\end{array}$} & Shoot & V. vitis-idaea & - & - & - & - & - & - & - & - & - & - & - & - \\
\hline & & C. epigejos & - & - & - & - & - & - & - & - & - & - & - & - \\
\hline & & R. acetosella & - & - & - & - & - & - & - & - & - & - & - & - \\
\hline & Root & V. vitis-idaea & - & - & - & - & * & - & - & * & * & - & * & - \\
\hline & & C. epigejos & * & - & - & - & - & - & - & - & - & - & - & - \\
\hline & & R. acetosella & - & - & - & - & - & - & - & - & - & - & - & - \\
\hline
\end{tabular}

Interaction between dominant species and temperature

The results obtained from the analysis of variance (Tab. 5) showed that temperature (as a fixed effect) as well as the interaction of dominant extracts and temperature (as a random effect) had a significant impact on pine seed germination $(p<0.05)$ and the concentration of chlorophyll $a(p<0.001$ and $p<0.01$, respectively), chlorophyll $b$ $(p<0.001$ and $p<0.05$, respectively), and carotenoids $(p<0.001$ and $p<0.05$, respectively).

The variability of the radicle $(p<0.01)$ and hypocotyl $(p<0.05)$ lengths was most affected by the interaction of dominant species and temperature. Temperature and dominant species were the primary factors that contributed to the largest variability of the obtained data. Moreover, it was deter-
Tab. 4 - Evaluation of differences in chlorophyll and carotenoid concentrations (mg $\left.\mathrm{g}^{-1}\right)$ along the temperature gradient according to the Kolmogorov-Smirnov test. $\left(^{*}\right)$ : $p<0.05 ;(* *): p<0.01 ;(* * *): p<0.001$.

\begin{tabular}{|c|c|c|c|c|c|c|c|c|c|c|c|c|c|}
\hline \multirow{3}{*}{ 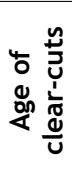 } & \multirow{3}{*}{ Extract } & \multirow{3}{*}{$\begin{array}{l}\text { Dominant } \\
\text { species }\end{array}$} & \multicolumn{11}{|c|}{ Temperature $\left({ }^{\circ} \mathrm{C}\right)$} \\
\hline & & & 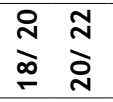 & 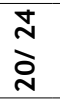 & $\begin{array}{l}\underset{N}{\infty} \\
-\end{array}$ & 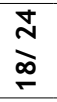 & 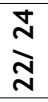 & $\begin{array}{l}\text { 요 } \\
\stackrel{\infty}{-}\end{array}$ & & 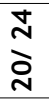 & $\underset{N}{\stackrel{N}{\infty}}$ & 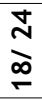 & 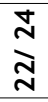 \\
\hline & & & \multicolumn{5}{|c|}{ Chlorophyll $a / b$} & \multicolumn{6}{|c|}{ Carotenoid } \\
\hline \multirow{5}{*}{$\begin{array}{l}\text { 믕 } \\
\text { 녹 } \\
\text { 굼 }\end{array}$} & Shoot & P. schreberi & * & $* *$ & * & ** & ** & - & - & - & - & ** & - \\
\hline & & V. vitis-idaea & - & $* * *$ & ** & $* * *$ & - & * & - & ** & ** & - & ** \\
\hline & & C. vulgaris & $* * *$ & $* * *$ & ** & $* * *$ & - & & ** & - & - & - & - \\
\hline & Root & V. vitis-idaea & - & $* * *$ & - & *** & * & - & - & - & - & - & - \\
\hline & & C. vulgaris & * & *** & - & *** & - & - & - & - & - & - & - \\
\hline \multirow{6}{*}{$\begin{array}{l}\text { 뭉 } \\
\dot{1} \\
\frac{\lambda}{\lambda} \\
\dot{\sim}\end{array}$} & Shoot & V. vitis-idaea & $* *$ & $* * *$ & ** & $* * *$ & - & - & - & ** & - & ** & * \\
\hline & & C. epigejos & ** & $* *$ & * & ** & - & - & * & - & - & - & ** \\
\hline & & R. acetosella & $* * *$ & $* * *$ & $* * *$ & $* * *$ & * & * & ** & - & $* * *$ & * & ** \\
\hline & Root & V. vitis-idaea & $* *$ & $* *$ & $* *$ & $* *$ & - & - & - & - & - & - & ** \\
\hline & & C. epigejos & $* * *$ & *** & ** & $* * *$ & * & - & - & - & * & - & * \\
\hline & & R. acetosella & ${ }^{* *}$ & $* * *$ & $* *$ & $* * *$ & $* *$ & - & - & - & * & - & ** \\
\hline & & & \multicolumn{5}{|c|}{ Chlorophyll $a$} & \multicolumn{6}{|c|}{ Chlorophyll b } \\
\hline \multirow{5}{*}{$\begin{array}{l}0 \\
0 \\
1 \\
\frac{1}{\lambda} \\
\dot{1}\end{array}$} & Shoot & P. schreberi & $-\quad-$ & $* *$ & - & ** & ** & - & $*$ & $* *$ & $* * *$ & ** & - \\
\hline & & V. vitis-idaea & ** & $* * *$ & ** & *** & - & * & - & - & $* * *$ & $* * *$ & - \\
\hline & & C. vulgaris & $* * *$ & $* * *$ & ** & $* * *$ & * & - & ** & ** & - & - & - \\
\hline & Root & V. vitis-idaea & - & *** & - & *** & * & - & - & ** & - & - & - \\
\hline & & C. vulgaris & $* *$ & $* * *$ & - & $* * *$ & $* *$ & - & - & - & * & ** & - \\
\hline \multirow{6}{*}{$\begin{array}{l}\frac{0}{0} \\
\dot{1} \\
\grave{\lambda} \\
\dot{\sim}\end{array}$} & Shoot & V. vitis-idaea & * & $* * *$ & - & *** & * & - & * & $* *$ & * & ** & - \\
\hline & & C. epigejos & $* *$ & $* *$ & ** & *** & * & - & * & - & * & - & - \\
\hline & & R. acetosella & $* * *$ & $* * *$ & *** & *** & - & - & * & *** & $* * *$ & *** & - \\
\hline & Root & V. vitis-idaea & - & $* *$ & * & ** & * & - & ** & - & $* * *$ & ** & ** \\
\hline & & C. epigejos & $* *$ & *** & ** & *** & * & * & - & ** & *** & *** & - \\
\hline & & R. acetosella & $* *$ & $* * *$ & $* *$ & $* * *$ & $* *$ & - & $* *$ & $* *$ & $* *$ & $* * *$ & * \\
\hline
\end{tabular}


Tab. 5 - Variance components and standard errors of random effects as well as the $F$ criterion and significance ( $p$-value) of fixed effects from separate analyses for each trait. (Interaction): variance component of interaction between dominant species and temperature $(\%, \pm$ standard error, SE). $(*): p<0.05 ;(* *): p<0.01 ;(* * *): p<0.001$.

\begin{tabular}{lccccccc}
\hline Parameter & $\begin{array}{c}\text { Interaction } \\
(\%) \pm S E\end{array}$ & $\operatorname{Pr}>$ Z & \multicolumn{2}{l}{ Temperature } & \multicolumn{2}{l}{$\mathrm{pH}$} \\
\cline { 5 - 8 } & & & $F$ criterion & $p$-value & $F$ criterion & $p$-value \\
\hline Germination & $7.11 \pm 4.02$ & $*$ & 4.73 & $*$ & 6.38 & $* *$ \\
Radicle length & $22.17 \pm 5.77$ & $* *$ & 2.78 & - & 2.23 & - \\
Hypocotyl length & $21.75 \pm 9.47$ & $*$ & 3.00 & - & 0.19 & - \\
Chlorophyll $a$ & $25.33 \pm 9.76$ & $* *$ & 39.70 & $* * *$ & 9.31 & $* *$ \\
Chlorophyll $b$ & $14.16 \pm 6.15$ & $*$ & 20.79 & $* * *$ & 4.05 & $*$ \\
Chlorophyll a/b & $10.42 \pm 1.06$ & $*$ & - & - & 3.09 & $*$ \\
Carotenoid & $13.85 \pm 6.03$ & $*$ & 11.79 & $* * *$ & 0.67 & - \\
\hline
\end{tabular}

mined that the extract $\mathrm{pH}$ values significantly impacted the seed germination rate $(p<0.01)$ and chlorophyll concentration $(p<0.05$ to $p<0.001)$. A statistically significant weak positive correlation was deter mined between extract $\mathrm{pH}$ and both seed germination rate $(r=0.27)$ and chlorophyll concentration ( $r=0.11$ - data not shown).

\section{Discussion}

The present study was designed to determine the allelopathic activity of aqueous extracts produced from the shoots and roots of the 1-yr-old and 2-yr-old dominant plants growing in the clear-cuts of Scots pine stands in response to different temperature regimes ex situ. Ping et al. (2009) noted that temperature can be considered as one of the most important factors promoting the allelopathic potential of plants. The results of the current study show that the inhibitory effect of the extracts of dominants on Scots pine seedlings directly correlates with temperature. This response could depend on altered microclimatic conditions after forest clear cutting (increased light and temperature), which accelerates the growth of these species. Temperature is a critical driver for plant distribution at the global scale, because it strongly influences seed germination, growth, and survival at the population scale (Diemer 2002 Walck et al. 2011). Tang et al. (1995) indicated that stressful conditions cause higher concentrations of allelochemicals. These findings correspond to our data re garding seed germination observed for all extracts at the highest tested temperature, which was identified as the most unfavourable for seeds. Matias \& Jump (2014) pointed out that seed germination and early seedling growth and survival are the most vulnerable life stages of trees. Seedlings and young saplings are more sensitive to abiotic conditions than trees because of their limited root system, therefore, they respond more rapidly to environmental changes than adult trees (Lloret et al. 2009). For this reason, early stages are expected to represent the critical stage in plants during experiments.

Our findings indicated that seed germination inhibition significantly increased when the temperature increased from 20 to 24 ${ }^{\circ} \mathrm{C}$. These results match with those observed in previous studies showing that increased temperature stimulates the production of higher allelochemical concentrations, which could have stronger effects on acceptor species (Wang et al. 2011, Zhang et al. 2014). However, our results indicated a different response of the root and shoot extracts of dominant species to seed germination at all temperatures compared with the data obtained in previous studies (Mahmoodzadeh et al. 2015, Gulzar \& Siddiqui 2014). A weaker inhibition of root extracts has been specified for other plant species, for example Heracleum mantegazzianum (Apiaceae - Balezentiene \& Renćo 2014). Our study indicated that aqueous root extracts provided lower inhibitory effects than did shoot extracts. The different responses of the studied species (Wang \& Wang 2006) to shoot and root extracts might be due to evolutionary differences in resistance to allelopathic compounds among acceptor species. The different allelopathic effects of the shoots and roots of dominant species has also been documented by other authors (Gulzar \& Siddiqui 2014). Mahmoodzadeh et al. (2015) noted that the different qualitative composition and quantitative content of biologically active compounds might explain the different effects of shoots and roots of dominant species. Moreover, the inhibitory effect of extracts from different parts of plant dominants on seed germination at all temperatures might be due to imbalance in metabolism regulated by various enzyme activities (Oyun 2006). The structure of plasma membrane might have become denatured by the allelochemicals present in shoot extract.

Seedling parts exhibited different responses to dominant extracts. The extracts prepared from tested species inhibited the radicle growth of pine seedlings more than hypocotyl growth at all temperatures. These findings agree to the results of previous studies indicating that seedling roots are more sensitive to allelochemicals than shoots (Zhang et al. 2014).

Some authors (Givnish 1988, Yamazaki et al. 2005) indicate that the ratio of chloro- phyll $a$ to $b(\mathrm{Chl} a / b)$ is a key parameter of plant response to environmental factors. The results of our study indicated that the $\mathrm{Chl} a / b$ ratio in the control pine seedlings increased along the temperature gradient. Some authors suggested that such a process might be related to a decrease in chlorophyll $a / b$-binding proteins, which could reduce the risk of photooxidative damage due to the relative decrease in the absorption cross-section of photosystems (Cui et al. 2006). Alexieva et al. (2003) indicated that such plant reactions might depend on plant adaptations to changing conditions, i.e., protective reactions to stress factors, such as increasing temperature in our case. Climate change can challenge the adaptive capacity of many long-lived species as trees, probably exceeding their migration capacity (Rehfeldt et al. 2002). Existing local adaptations that allow individuals to tolerate environmental conditions are especially important in order to increase the resistance and resilience of current populations. In summary, our results demonstrate the relation between the chlorophyll concentration and growth parameters (radicle and hypocotyl length) of pine seedlings. Heidarzadeh et al. (2012) suggested that the seedling parameters of radicle length and chlorophyll content and the seed parameter of germination rate could be used as key parameters in such studies, because these traits respond more sensitively to allelochemicals. Plant allelochemicals adversely affect chlorophyll biosynthesis and accumulation by interfering in chlorophyll biosynthesis and/or destruction, and the subsequent negative effects of these processes inhibit photosynthesis and plant growth (Rashed Mohasel \& Moosavi 2007). Previous studies reported that carotenoids not only are involved in photosynthesis but also act as antioxidants, protecting cells against environmental stress (Alexieva et al. 2003). The results of this study indicated that increasing the ambient temperature up to $24{ }^{\circ} \mathrm{C}$ stimulates the increase in carotenoids concentration, which promotes the development of resistance mechanisms in pine seedlings. A strong decrease in carotenoid concentration in the control at the highest $\left(24{ }^{\circ} \mathrm{C}\right)$ temperature indicated pine intolerance for significantly elevated environmental temperatures. Moreover, our results indicate that the extracts of all dominant species stimulate carotenoid concentration at the highest tested temperature. Einhelling (1989) noted that allelopathic interactions affect both the aggressiveness of donor species and the resistance of acceptor species. It has been reported that Scots pine seedlings have a very low drought resistance when compared with other cohabiting Mediterranean species (Matias et al. 2012). Plant responses and resistance to different environmental conditions depend on the genetic and physiological properties of species. Complexes consisting of chlorophyll and carotenoid molecules drive the elec- 
tron transport chain during the photosynthetic process by absorbing light quantum energy. Consequently, the concentration and ratio of these pigments should not limit regular photosynthetic activity (Balčiunas et al. 2008). It can therefore be assumed that the new findings obtained regarding the changes in the allelopathic potential of dominant species in the clearcuts of previous Scots pine stands in $\mathrm{Li}$ thuania improve our understanding of the impact of allelopathy on reforestation and management of forest ecosystems under changing climatic conditions.

\section{Conclusions}

The inhibitory allelopathic effects of aqueous extracts depend on dominant species, plant part and ambient temperature.

The assessment of temperature impact (temperature increases from $18{ }^{\circ} \mathrm{C}$ to $24{ }^{\circ} \mathrm{C}$ with $2{ }^{\circ} \mathrm{C}$ increments) revealed increased inhibitive properties of dominant extracts with increasing temperature, in terms of decreased seed germination, hypocotyl height and root length.

The chlorophyll $a / b$ ratio in Scots pine seedlings decreased along an increasing temperature gradient for most of extracts of dominant species. The carotenoid concentration non-significantly increased with increasing temperature from 18 to $22{ }^{\circ} \mathrm{C}$. However, this concentration was significantly reduced at $24^{\circ} \mathrm{C}$. The highest variability in photosynthetic pigment concentration was induced by different temperatures $(p<0.001)$. The lowest carotenoid concentration of $0.02 \mathrm{mg} \mathrm{g}^{-1}$ was observed in the control pine seedlings at the maximum temperature of $24^{\circ} \mathrm{C}$, which caused a decrease in pine adaptive capacity, i.e., the lowest seed germination and seedling growth.

The results of this study make it possible to conclude that Scots pine resistance to the highest temperature tested was considerably lower than the biochemical impact obtained from the extracts of the dominant species. Consequently, an evident increase in ambient temperature might create unfavourable conditions for the regeneration of boreal tree species such as Scots pine, ultimately resulting in a treeline shifts under a changing climate.

\section{Acknowledgements}

The paper presents the findings obtained through the long-term research programme "Sustainable Forestry and Global Changes" implemented by the Lithuanian Research Centre for Agriculture and Forestry.

\section{References}

Alexieva V, Ivanov S, Sergiev I, Karanov E (2003). Interaction between stresses. Bulgarian Journal of Plant Physiology 29: 1-17. [online] URL: http://www.esalq.usp.br/lepse/imgs/conteudo_ thumb/Interaction-bewteen-stresses-1.pdf

Balčiunas M, Jankauskiene Z, Brazaityte A, Du- chovskis $P$ (2008). The effect of plant stand density on plant leaf area index and content of photosynthetic. Zemdirbyste - Agriculture 95 (4): 97-109.

Balezentiene L, Renćo M (2014). The phytotoxicity and accumulation of secondary metabolites in Heracleum mantegazzianum (Apiaceae). Allelopathy Journal 33 (2): 267-276.

Balezentiene L, Seziene V (2010). Biochemical impact of dominant's of Scots pinewood cutting on germination. Polish Journal of Environmental Studies 19 (1): 35-42.

Benyas E, Hassanpouraghdam MB, Zehtbsalmasi S, Khatamian Oskooei OS (2010). Allelopathic effects of Xanthium strumarium L. shoots aqueous extracts on germination, seedlings growth and chlorophyll content of lentil (Lens culinaris Medic.). Romanian Biotechnological Letters 15 (3): 5223-5228. [online] URL: http://www.res earchgate.net/publication/233842865

Braun-Blanquet J (1964). Pflanzensoziologie. Grundzüge der Vegetationskunde. [Plant sociology. Basics of vegetation science] ( $3^{\text {rd }}$ edn). Springer, Wien, Autsria and New York, USA, pp. 865.

Cui LJ, Li JL, Fan YM, Zhang Z (2006). High temperature effects on photosynthesis, PSII functionality and antioxidant activity of two Festuca arundinacea cultivars with different heat susceptibility. Botanical Studies 47 (1): 61-69. [online] URL: http://pdfs.semanticscholar.org/ 3786/d1211bf37d2ofoee0365098f733592f59c58. pdf

Diemer M (2002). Population stasis in a high-elevation herbaceous plant under moderate climate warming. Basic and Applied Ecology 3: 7783. - doi: 10.1078/1439-1791-00079

Donnelli MJ, Green DM, Walters LJ (2008). Allelopathic effects of the Brazilian pepper Shinus terebinthifolius on growth, leaf production and biomass of seedlings of the red mangrove Rhizophora mangle and the black mangrove Avicennia germinans. Journal of Experimental Marine Biology and Ecology 357: 149-156. - doi: 10.1016/j.jembe.2008.01.009

Donohue KR, De Casas R, Burghardt L, Kovach K, Willis C (2010). Germination, postgermination adaptation, and species ecological ranges. Annual Review of Ecology, Evoluation and Systematics 41: 293-319. - doi: 10.1146/annurev-ecol sys-102209-144715

Einhelling FA (1989). Interactive effects of allelochemicals and environmental stress. In: "Phytochemical Ecology: Allelochemicals, Mycotoxins and Insect Pheromones and Allomones" (Chou $\mathrm{CH}$, Waller GR eds). Institute of Botany, Academia Sinica Monograph Series, Tapei, Taiwan, vol. 9, pp. 101-118.

Givnish TJ (1988). Adaptation to sun and shade: a whole-plant perspective. Australian Journal of Plant Physiology 15: 63-92. - doi: 10.1071/PP9 880063

Gulzar A, Siddiqui MB (2014). Allelopathic effect of aqueous extracts of different part of Eclipta alba (L.) Hassk. on some crop and weed plants. Journal of Agricultural Extension and Rural Development 6 (1): 55-60. - doi: 10.5897/JAERD20 13.0542

Heidarzadeh A, Pirdashti H, Esmaeili M (2010). Quantification of allelopathic substances and inhibitory potential in root exudates of rice
(Oryza sativa) varieties on Barnyardgrass (Echinochloa crus-galli L.). Plant Omics 3: 204-209. Heidarzadeh A, Pirdashti H, Esmaeili MA, Asghari $J$ (2012). Inhibitory activity of allelochemicals on barnyardgrass (Echinochloa crus-galli L.) seed and seedlings parameters. World Applied Sciences Journal 17 (11): 1535-1540.

ISTA (2007). ISTA method validation for seed testing. The International Seed Testing Association (ISTA), Bassersdorf, Switzerland, pp. 66.

Lloret F, Peñuelas J, Prieto P, Llorens L, Estiarte $M$ (2009). Plant community changes induced by experimental climate change: seedling and adult species composition. Perspectives in Plant Ecology, Evolution and Systematics 11: 5363. - doi: 10.1016/j.ppees.2008.09.001

Berner LT, Beck PA, Bunn AG, Goetz SJ (2013). Plant response to climate change along the forest-tundra ecotone in northeastern Siberia. Global Change Biology 19 (11): 3449-3462. - doi: 10.1111/gcb.12304

LR-AM/LMI/VMT (2006). Forest site types (Vaičys $M$ ed). LUTUTE, Kaunas, Lithuania, pp. 95. [in Lithuanian]

Mahmoodzadeh $\mathrm{H}$, Ghasemi $\mathrm{M}$, Zanganeh $\mathrm{H}$ (2015). Allelopathic effect of medicinal plant Cannabis sativa L. on Lactuca sativa L. seed germination. Acta agriculturae Slovenica 105 (2): 233-239. - doi: 10.14720/aas.2015.105.2.06

Matias L, Quero JL, Zamora R, Castro J (2012). Evidence for plant traits driving specific drought resistance. A community field experiment. Environmental and Experimental Botany 81: 55-61. - doi: 10.1016/j.envexpbot.2012.03.002 Matias L, Jump AS (2014). Interactions between growth, demography and biotic interactions in determining species range limits in a warming world: the case of Pinus sylvestris. Forest Ecology and Management 282: 10-22. - doi: 10.1016/j. foreco.2012.06.053

Oyun MB (2006). Allelopathic potentialities of Gliricidia sepium and Acacia auriculiformis on the germination and seedling vigour of maize. American Journal of Agricultural and Biological Sciences 1 (3): 44-47. - doi: 10.3844/ajabssp.20 06.44.47

Ping P, QuanZhi X, PinWu L, YuJia H, Xiang H, Qiamg $L$ (2009). Studies on the allelopathy components of tea. Southwest China Journal of Agriculture Sciences 22 (1): 67-70. [online] URL: http://www.cabdirect.org/cabdirect/abstract/2 0093099915

Rashed Mohasel MH, Moosavi SK (2007). Principles of weed management. Ferdowsi University of Mashhad Publication, Mashhad, Iran, pp. 273-290.

Rehfeldt GE, Tchebakova NM, Parfenova YI, Wykoff WR, Kuzmina NA, Milyutin LI (2002). Intraspecific responses to climate in Pinus sylvestris. Global Change Biology 8: 912-929. - doi: 10.1046/j.1365-2486.2002.00516.x

Ruan X, Pan CD, Liu R, Li ZH, Jiang DA, Zhang JC, Wang G, Zhao YX, Wang Q (2016). Effects of climate warming on plant autotoxicity in forest evolution: a case simulation analysis for Picea schrenkiana regeneration. Ecology and Evolution 6 (16): 5854-5866. - doi: 10.1002/ece3.2315 Santos MG, Ribeiro RV, Machado EC, Pimentel C (2009). Photosynthetic parameters and leaf water potential of live common bean genotypes under mild water deficit. Biologia Plan- 
tarum 53: 229-236. - doi: 10.1007/s10535-009-00 44-9

SAS Institute Inc. (2010). SAS/STAT User's Guide, Version 9.3. Cary, NC, USA.

Seziene V, Balezentiene L, Maruška A (2017). Identification and biological activity of phenolic compounds in dominant' extracts of pine forest clear-cuts. iForestry - Biogeosciences and Forestry 10: 309-314. - doi: 10.3832/ifor1791-009 Tang CS, Cai WF, Kohl K, Nishimoto RK (1995). Plant stresses and allelopathy. In: "Allelopathy: Organisms, Processes and Applications" (Inderjit, Dakshini KMM, Einhellig FA eds). American Chemical Symposium Series No. 585. American Chemical Society, Washington, DC, USA, pp. 142-157.

UNFCCC (2016). The Paris Agreement. Web site. [online] URL: http://unfccc.int/paris_agreement /items/9485.php

Vanderstukken M, Declerck S, Decaestecker E, Muylaert K (2014). Long-term allelopathic control of phytoplankton by the submerged macrophyte Elodea nuttallii. Freshwater Biology 59: 930-941. - doi: 10.1111/fwb.12316

Walck JL, Hidayati SN, Dixon KW, Thompson K,
Poschlod P (2011). Climate change and plant regeneration from seed. Global Change Biology 17: 2145-2161. - doi: 10.1111/j.1365-2486.2010.0236 8.x

Wang R, Wang YZ (2006). Invasion dynamics and potential spread of the invasive alien plant species Ageratina adenophora (Asteraceae) in China. Diversity and Distributions 12: 397-408. doi: 10.1111/j.1366-9516.2006.00250.x

Wang RL, Zeng RS, Peng SL, Chen BM, Liang XT, Xin XW (2011). Elevated temperature may accelerate invasive expansion of the liana plant Ipomoea cairica. Weed Research 51: 574-580. - doi: 10.1111/j.1365-3180.2011.00884.x

Wardle DA, Karban R, Callaway RM (2011). The ecosystem and evolutionary contexts of allelopathy. Trends in Ecology and Evolution 26: 655-662. - doi: 10.1016/j.tree.2011.08.003 Wettstein D (1957). Chlorophyll Letale und der submikroskopishe Formveschsel der Plastiden [Chlorophyll Letale and the submicroscopic form of the plastids]. Experimental Cell Research 12: 427. [in German]

WRB-IWG (2014). World reference base for soil resources 2014. International soil classification system for naming soils and creating legends for soil maps. World Soil Resources Reports No. 106. FAO, Rome, Italy, pp. 191.

Yamazaki J, Takahisa S, Emiko M, Yasumaro K (2005). The stoichiometry and antenna size of the two photosystems in marine green algae, Bryopsis maxima and Ulva pertusa, in relation to the light environment of their natural habitat. Journal of Experimental Botany 56 (416): 15171523. - doi: 10.1093/jxb/eri147

Zhang Q, Zhang Y, Peng S, Zobel K (2014). Climate warming may facilitate invasion of the exotic shrub Lantana camara. PLoS ONE 9 (9): e105500. - doi: 10.1371/journal.pone.0105500

\section{Supplementary Material}

Tab. S1 - Pigment concentration in Scots pine seedlings along the temperature gradient.

Link: Sirgedaite-Seziene_2904@supplo01.p df 